\title{
Factors Influencing Access to Secondary Education in Central Senatorial District of Ondo State, Nigeria
}

\author{
Ige Akindele Matthew $(\mathrm{PhD})^{*}$ \\ Director, Ministry of Education, Akure, Ondo State, Nigeria \\ *Corresponding Author \\ Ige Akindele Matthew (PhD)

\section{Article History} \\ Received: 20.07.2019 \\ Accepted: 06.08.2019 \\ Published: 11.11.2019
}

\begin{abstract}
The study investigated the perception of principals on factors influencing access to secondary education, with a focus on Public Secondary Schools in Central Senatorial District of Ondo State, Nigeria. It adopted descriptive design. All the 107 Public Secondary Schools in the District constituted the main population while principals of the schools were targets. One question was raised and four hypotheses formulated for the study. A self-constructed questionnaire, validated and tested for reliability $(r=0.80)$, was used to collect data, which were analysed using percentage, frequency count, mean and Statistical Package for Social Sciences (SPSS). Hypotheses were tested using chi-square statistic at 0.05 level of significance. It was found that many factors influenced access to secondary education, such as: inappropriate teaching method, unfavourable government policies, inadequate teachers, child ill health, among others. It was also revealed that home, school, and government factors significantly influenced access to secondary education while there was no significant difference in the perception of male and female principals, on factors influencing access. The study also recommend among others that Government should address the factors influencing access, through relevant policies and programmes; engage communities, homes and families in sensitization programmes towards discouraging them from culture, traditions and religious belief having negative influence on access to secondary education; as well as provide necessary infrastructural facilities for secondary schools, to enhance comfortability of students and teachers.
\end{abstract}

Keywords: factor, influence, access, education, secondary education, district, Nigeria.

\section{INTRODUCTION}

Secondary education is the education which is received after primary and before tertiary education. Apart from serving as the bridge between primary and tertiary education, it provides opportunity for a child to acquire additional knowledge, skills, values, and traits beyond the primary education. It is very critical in any nation because of the role it plays in national development. According to Ige [1], a major factor that necessitates the acquisition of secondary education in Nigeria is that the education being provided at primary level is proving to be insufficient for a child to acquire permanent literacy, communicative, and numeracy skills expected from $\mathrm{him} / \mathrm{her}$ at the end of the training. Ike [2] added that apart from the acquisition of knowledge and development of higher mental faculty of an individual, secondary education aspires to develop in a student, respect for the worth and dignity of the human person, faith in man's ability to make rational decisions, recognize his/her role as a citizen, particularly in relation to others in the society, demonstrate that he is an informed citizen, equipped with skills and attitudes for effective living and survival, as well as respect for dignity of labour.

Secondary education is aged in Nigeria, having developed alongside western education, introduced by the Christian Missionaries in 1842. At the onset, only primary education enjoyed the support of the Missionaries because it was used to woo the children into Christianity. Government's attention to secondary education started after the development of primary education, particularly when the need for outputs of primary schools to continue their education became paramount. Adesina [3] reported that the first secondary school (CMS Grammar School, Bariga, Lagos) was established by the Church Missionary Society, in 1859. Since then, government has shown keen interest in and commitment to the establishment of additional secondary schools, in a bid to increase access to secondary education and enable the citizens to enjoy the dividends. Statistics, in Nwagwu [4], revealed that as at 1970 , there were 310,054 secondary schools with 1,086 students, which increased to 2,769 schools and 1,553,345 students in 1980; 6,429

Copyright @ 2019: This is an open-access article distributed under the terms of the Creative Commons Attribution license which permits unrestricted use, distribution, and reproduction in any medium for non commercial use (NonCommercial, or CC-BY-NC) provided the original author and source are credited. 
schools and 4,448,988 students in 1995; and 10, 913 schools, 6, 397, 581 students in 2005, while as at 2016, there were 10,443,451 students in secondary schools [5].

\section{Secondary Education in Nigeria}

Secondary education is provided for children after primary education and before tertiary education. It is aimed at developing a child more than the level attained at the primary level, more so that it is becoming obvious that primary education is insufficient for children to acquire literacy, numeracy, and communication skills. Such education is provided in secondary school, owned by the government (state or federal), individuals or communities. It is divided into Junior Secondary and Senior Secondary phases.

The Junior Secondary phase has three years duration. The curriculum at this phase is pre-vocational and academic in scope. Core, pre-vocational and non-prevocational subjects are included in the curriculum. The core subjects include: English Language, Mathematics, French, and a major Nigerian language other than that of the environment, Basic Science, Social Studies, Citizenship Education, and Basic Technology. The pre-vocational subjects include Agricultural Science, Business Studies, Home Economics, Local Crafts, Fine Arts, Computer Education and Music while the non-prevocational subjects include Religious Knowledge, Physical and Health Education as well as Arabic.

Certification at the end of the JSS phase is based on the performance of a student in Continuous Assessment and the results of Junior Secondary Certificate Examination (JSCE), being coordinated by the State Examination's Board or Federal Government (if owned by Federal Government). A child is supposed to write the Junior Secondary Certificate Examination (JSCE) at the end of this phase. Success in the examination qualifies a child to proceed to the Senior Secondary (SS) phase where he/she will be trained for additional three years. A child that fails the JSCE is expected to enroll in a technical college, an out-of-school vocational training centre or an apprenticeship scheme, in line with the 6-3-3-4 system of education.

The Senior Secondary phase also has three years duration and follows the Junior Secondary phase. It has wider scope than the Junior Secondary School (JSS) phase and aims at broadening the knowledge and skill of a student beyond the level attained at the JSS level and thus prepares him/her for further education. It is academic and vocational in scope. A student is supposed to offer a minimum of seven and maximum of eight subjects, comprising the six core subjects: English Language, Mathematics, a major Nigerian language, one science, an art, and a vocational subject. One or two other electives are to be selected from the art, science, technical, social science, and vocational subjects.

Certification at the end of the SS phase is based on the performance of a student in the Continuous Assessment and the Senior Secondary Certificate Examination (SSCE), being coordinated by West African Examinations Council (WAEC) and National Examinations Council (NECO). A student has to pass with minimum credits (i.e. five credits at two sittings including English Language and Mathematics) to be able to proceed to tertiary level of the educational system.

\section{In Nigeria, Secondary education aims at preparing an individual for}

- Useful living within the society, and

- Higher education.

\section{Specifically, it aims at}

- providing all primary school leavers with the opportunity for education of higher level, irrespective of sex, social status, religious or ethnic background;

- offering diversified curriculum, to cater for differences in talents, opportunities, and future roles;

- providing trained manpower in applied science, technology and commerce at sub-professional grades;

- developing and promoting Nigerian languages, arts and culture, in the context of the world's cultural heritage;

- inspiring student with a desire for self-improvement and achievement of excellence;

- fostering national unity, with an emphasis on the common ties that unite us in our diversity;

- raising a generation of people who can think for themselves, respect the views and feelings of others, respect the dignity of labour, appreciate those values specified under our broad national goals, and live as good citizens; and

- providing technical knowledge and vocational skills, necessary for agricultural, industrial, commercial, and economic development [6]

\section{State of Access to Secondary Education in Nigeria}

According to Okeke [7], access to education means the free, unlimited, unhindered, and unfettered opportunities at each level of education, to obtain knowledge, skills, and abilities available at that level, needed to optimally participate and contribute to development in the society. This connotes enrolling, attending, and completing education at that level and if possible, transiting to the next level of education. Kuraja [8] sees access to education as the enrolment of a person in an education institution, giving him/her an opportunity to participate in learning in a formal institution, involving both enrollment and attendance in an education institution. In the light of the definitions, lack of access to education means: failing to enroll in educational institution; lack of opportunities to attend 
school regularly, inability to complete the prescribed programme of study (leading to school dropouts), inability to attain a set goal, and inability to transit to the next level of education [10].

Over the years, access to secondary education remains an issue of concern in Nigeria. In spite of the continued increase in access to secondary education in Nigeria (as indicated in para.2 of the paper), the demand for secondary education has not been fully met $[11,12]$.

Table-1: Gross Enrolment Ratio in Secondary Education (as Percentage of Population of Secondary School Age Children) in 20 Selected Countries, Nigeria inclusive: 2010-2015

\begin{tabular}{|l|l|}
\hline Country & Secondary (\%) \\
\hline United States of America & 98.0 \\
\hline Germany & 102.0 \\
\hline Canada & 110.0 \\
\hline Switzerland & 100.0 \\
\hline Sweden & 133.0 \\
\hline France & 111.0 \\
\hline Bulgaria & 101.0 \\
\hline Brazil & 102.0 \\
\hline Turkey & 100.0 \\
\hline New Zealand & 117.0 \\
\hline Japan & 102.0 \\
\hline Algeria & 100.0 \\
\hline Australia & 138.0 \\
\hline Egypt & 86.0 \\
\hline Togo & 90.0 \\
\hline Morocco & 69.0 \\
\hline Saudi Arabia & 108.0 \\
\hline X Nigeria & 44.0 \\
\hline Tunisia & 88.0 \\
\hline Togo & 90.0 \\
\hline
\end{tabular}

Source: United Nations Development Programme [12]. Human Development Report

As indicated in Table 1, Nigeria ranked least among the countries in the different continents in the world (i.e. Africa, North America, South America, Europe, Asia and Oceania), in terms of gross enrolment rate in secondary education.

\section{Statement of Problem}

In spite of the efforts of government and other stakeholders in education towards ensuring that all school-age children, who are willing to receive secondary education are given the opportunity, access to secondary education has remain unholistic in Nigeria. There are wide disparities between the expected and actual enrolment in secondary schools, thus implying that many secondary school-age children are not enrolled in schools. The inability of children to have access to secondary education has been encouraging many children to terminate their education prematurely, reducing literacy rate, as well as drawing the hands of the clock of the country backward, particularly in her efforts to achieve the Sustainable Development Goals. Even though there are studies on issue of access to education in literature, those on secondary education, particularly those that address the challenges of access, are insignificant, is spite of the effects in the educational system. The study is thus geared towards addressing this shortcoming.

\section{Purpose of the Study}

The study was meant to investigate the factors influencing access to secondary education in Central Senatorial District of Ondo State, Nigeria. The study also found if home, school, and government based factors have significant effects on access to secondary education; and if there was significant difference in the perception of male and female principals, on factors influencing access to secondary education.

\section{Significance of the Study}

The findings of the study will keep government abreast of factors influencing access to secondary education in Nigeria, which will serve as clue towards tackling those factors and improving the state of secondary education in the country. Findings of the study will also serve as insights to secondary schools administrators towards playing their role, to improve access at this level of the educational system. It will also assist the Ministry of Education to gather information on the state of access to secondary education in the rural and remote areas of the country.

In addition, the report of the study can serve as guide to future and current researchers in the field of Educational Planning and Administration. 


\section{Research Questions}

The following questions guided the study

- What are the factors influencing access to secondary education in Nigeria?

\section{HYPOTHESES}

\section{The following hypotheses guided the study}

- Home based factors have no significant effect on access to secondary education.

- School based factors have no significant effect on access to secondary education.

- Government based factors have no significant effect on access to secondary education.

- There is no significant difference in the perception of male and female principals on factors influencing access to secondary education in Nigeria.

\section{Factors Influencing Access to Education: Literature Review}

There are factors that influence access of children to education. Wikan [13], cited in Kepng'etich., Boit., and Bonnett [14] identified government policies, school factors, as well as household/family factors. Calchough, Sammer and Rose [15], also cited in Kepng'etich., Boit., and Bonnett [14] listed cost of school participation, school quality, physical facilities and scarce resources in school as factors that affect access to primary school education among children from households that are poor. According to Wachiye and Nasongo [16], access to secondary education remains strongly associated with household wealth. World Bank [17] also listed non-school factors, such as education of parents, child rearing practices, nutrition, health care and pre-school education as factors having more effect on children access to education, as well as positive school factors, such as teachers and books have more effects in developed countries than in developing countries.

Also, Kuranja [8] investigated the home based factors influencing access to Early Childhood Education in Limuru District of Kenya. He found payment of user fees by parents, lack of awareness by parents, distance to school, and large family size as factors that influenced access. A study, conducted by Action Aid, cited in Igbuzor [18], observed that the reasons why scholars do not go to schools include: high cost of tuition fees, health challenge, hunger, and educational background of parents. Uduak [19] also investigated access and equalization of university educational opportunities in Nigeria and found that access to university education is hindered by carrying capacity, poor funding, and exorbitant charges.

Kepng'etich., Boit., and Bonnett [14] investigated the factors influencing household decisions on access to Primary School Education in Kenya, being a case study of Uasin Gishu West District. The study found that household factors can deter many household not to have their children in school while school related factors can encourage many household to send their children and have them continuously in school. According to Limaye [20], factors that influenced the accessibility of education for children with disabilities in India are: perceptions of parents of children with disabilities and their difficulties in helping their children with disabilities, general attitude of society, government officials, school staff and infrastructure, inadequate levels of training of key stakeholders, invisibility of disability in community, poverty, lack of acceptance, lack of interest, gender discrimination, lack of awareness, poor physical access, availability of various support systems, and government policies focusing on the education of children with disabilities in specific.

A study, conducted by Mollel and Chong [21], on the socio-cultural constraints of girls' access to education in Mtwara District of Tanzania, found early marriage, negative perception of girls education, traditional ceremonies (Unyago), social roles, and male preference as constraints to access to education. Another study, by Kamanja [22], on the factors influencing boy-child secondary education in the Rice growing region of Kirinyaga South District, Kirinyaga County, Kenya found levies imposed by schools, level of education, age and gender of household's head, lack of interest, distance between homes and schools, as well as household size as factors that influenced boy-child education in the region.

Ngware et al. [23] investigated the factors that influenced access to secondary education and strategies for improving access to secondary education in Kenya and found household's income, education level of household head, household residence, sex of child, availability of schools, and age of child as main factors. Okumu [24] studied the socio-economic factors influencing students' access to secondary school education in Rongo District of Kenya.The study found that the socio-economic factors that had the highest effects in access of students in secondary school education to be size of the family, income of parents, child labour and tuition fee, while other home based factors as HIVIAIDS, parental level of education school affected access of students in secondary school.

In addition, Isaac and Ojo [25] in a study of the determinants of access to education and ICT in Nigeria, using information from 4,508 households from National Bureau of Statistics Household Survey Data, found that age, years of education, marital status, gender, as well as household size, influenced access to education. 


\section{Methodology}

\section{Research Design}

The researcher adopted descriptive design, because it uses data and information to describe the state of access to secondary education, from the perspective of the factors influencing it.

\section{Population of Study}

All the 107 Public Secondary Schools in the Central Senatorial District of the state constituted the main population while Principals of the schools were the targets.

\section{Sample and Sampling Techniques}

One Senatorial District, six Local Government Areas and one hundred and seven (107) Public Secondary Schools were used for the study. The Senatorial District (Ondo Central) comprises of Akure South, Akure North, Ondo West, Ondo East, Ifedore and Idanre Local Government Areas. All the 107 Public Secondary Schools in the district were used for the study. There was therefore no sampling for the study.

\section{Instrument}

A questionnaire was designed and used to collect data for the study. The questionnaire comprises of Section A and B. Section A consisted of questions and statements, aimed at eliciting the background information of respondents, principally their years of experience, gender, qualification, status in school, marital status, etc. Section B focused on challenges of access to secondary education in Ondo State, which forms the theme of the study. The section consisted of close-ended questions which required the respondents to tick the best option in response to each statement, and was structured on a four- point scale, Strongly Agree, Agree, Disagree, and Strongly Disagree. This special scale was adopted because of the perception of the researcher that the inclusion of the option 'undecided' was not necessary because of the confusion it creates for respondents.

\section{Validity and Reliability of Instrument}

Draft of the questionnaire was given to a professional colleague, for comments. After taking into cognizance the suggestions/comments, the final draft of the questionnaire was prepared for administration. The questionnaire was pilot-tested in ten (10) public secondary schools that were not used for the study, within an interval of two weeks. Responses to the items in the questionnaire in the two attempts were correlated using Pearson Product Moment Correlation Coefficient. A reliable coefficient ( $r$ ) of 0.80 was obtained.

\section{Method of Data Collection and Analysis}

The researcher visited all the selected Public Secondary Schools, accompanied by an Assistant. The researcher, with the help of the assistant, established rapport with the schools administrators and teachers on their arrival. After formal introduction, the researcher and assistant explained to the respondents, the purpose of the study and guided them on how to complete the questionnaires. After two weeks, the researcher was able to retrieve the administered questionnaires. Data collected through the questionnaire were however analyzed using Statistical Package for Social Sciences (SPSS), while the hypotheses were tested using chi-square and t-test statistics.

\section{Data Presentation, Analysis and Discussion of Findings}

The researcher administered 107 Questionnaires, unfortunately, 105 were retrieved from the respondents. After several attempt were made to retrieve the two Questionnaires failed, the researcher proceeded on the analysis, more so that the inability to retrieve these will not have significant effect on the findings.

Table-2: Background Information of Respondents

\begin{tabular}{|l|l|l|l|}
\hline Variable & Grouping & Frequency & Percentage \\
\hline Age Range of School & Below 10 years & 3 & 4.8 \\
& Between 10-20 years & 7 & 6.7 \\
& Between 20-30 years & 45 & 41 \\
& Above 30 years & 50 & 47.6 \\
\hline Sex of Respondents & Male & 69 & 65.7 \\
& Female & 36 & 36 \\
\hline Marital Status & Single & 2 & 1.9 \\
& Married & 103 & 98.1 \\
\hline Highest Qualification & B.Sc/BA/HND/B.TECH & 38 & 36.2 \\
& B.Ed/BSC/B.A/ED & 30 & 28.6 \\
& BSC/HND/B.TECH+PGDE & 13 & 12.4 \\
& Others & 24 & 22.9 \\
\hline Level of Experience & Between 10-20 years & 9 & 8.6 \\
& Between 20-30 years & 27 & 25.7 \\
& Above 30 years & 9 & 65.7 \\
\hline
\end{tabular}


Distribution according to age range of respondents, as indicated in Table 2, revealed that $3(4.8 \%)$ of the respondents were below 10 years, $7(6.7 \%)$ were between $10-20$ years, $43(41 \%)$ were between $20-30$ years while the remaining 50 (47.6\&) were above 30 years. Respondent's sex shows that the highest number of respondent were male $69(65.7 \%)$ while the remaining were female $36(34.3 \%)$. Only $2(1.9 \%)$ of the respondents were single while the remaining $103(98.1 \%)$ were married. $38(36.2 \%)$ of the respondents had B.Sc/BA/HND/B. Tech, 30(28.6\%) had B.Ed/BSc./BA/ED, 13(12.4\%) had BSc./HND/B. Tech + PGDE while 24(22.9\%) possessed other certificate apart from those mentioned.. Also, 9(8.6\%) of the respondents had 10-20 years of experience, 27(25.7\%) had 20-30 years' experience while the remaining $69(65.7 \%$ ) had over 30 years' experience in the profession.

\section{Answers to Research Question}

What are the factors influencing access to secondary education?

Table-3: Factors Influencing Access to Secondary Education

\begin{tabular}{|c|c|c|c|c|c|c|c|}
\hline $\mathbf{S} / \mathbf{N}$ & Items & SA & A & D & SD & Mean & Remark \\
\hline 1 & Poverty of parents/guardians & 46 & 43 & 14 & 2 & 3.2667 & Agreed \\
\hline 2 & Culture, tradition or religious belief of the family & 26 & 47 & 28 & 4 & 2.9048 & Agreed \\
\hline 3 & Parents lack of interest and awareness in education & 31 & 39 & 29 & 6 & 2.9048 & Agreed \\
\hline 4 & Care of siblings/ or relatives & 26 & 42 & 23 & 14 & 2.7619 & Agreed \\
\hline 5 & Lack of education of parents/ guardians & 17 & 23 & 58 & 7 & 2.4721 & Rejected \\
\hline 6 & Unfavorable government policies & 68 & 31 & 3 & 3 & 3.5619 & Agreed \\
\hline 7 & Insufficient allocation to secondary school & 37 & 42 & 21 & 5 & 3.0571 & Agreed \\
\hline 8 & High cost/fee & 36 & 42 & 21 & 5 & 3.2476 & Agreed \\
\hline 9 & Selection method in Common Entrance Exams & 51 & 36 & 17 & 1 & 3.3048 & Agreed \\
\hline 10 & $\begin{array}{l}\text { Fear of high level unemployment in the country i.e. that job will not be available at the } \\
\text { end of tanning }\end{array}$ & 50 & 34 & 13 & 8 & 3.2000 & Agreed \\
\hline 11 & Inadequate teacher to teach students & 62 & 29 & 11 & 3 & 3.4268 & Agreed \\
\hline 12 & Inadequate infrastructural facilities & 40 & 53 & 11 & 1 & 3.2571 & Agreed \\
\hline 13 & Gender discrimination & 40 & 53 & 11 & 1 & 3.1619 & Agreed \\
\hline 14 & Insecurity in schools & 15 & 47 & 37 & 6 & 2.6762 & Agreed \\
\hline 15 & Avoidance of harassment or corporal punishment by student & 15 & 47 & 37 & 6 & 3.0571 & Agreed \\
\hline 16 & Inability to understand medium of instruction & 11 & 78 & 15 & 1 & 2.9429 & Agreed \\
\hline 17 & Poor quality of teaching by teacher & 24 & 61 & 17 & 3 & 3.009 & Agreed \\
\hline 18 & Irrelevant school curriculum & 28 & 53 & 21 & 3 & 3.009 & Agreed \\
\hline 19 & Long distance of home to school & 20 & 53 & 23 & 9 & 2.8000 & Agreed \\
\hline 20 & Limited admission spaces & 36 & 46 & 21 & 2 & 3.1048 & Agreed \\
\hline 21 & Inappropriate teaching method & 32 & 58 & 15 & 1 & 2.4381 & Rejected \\
\hline 22 & Perception that a child is too young or immature to attend school & 17 & 54 & 28 & 6 & 2.27810 & Rejected \\
\hline 23 & Lack of water and sanitation in school & 17 & 50 & 28 & 18 & 2.7048 & Agreed \\
\hline 24 & Negative attitude of teachers & 31 & 45 & 26 & 3 & 2.9905 & Agreed \\
\hline 25 & Child ill health & 31 & 42 & 25 & 7 & 2.9238 & Agreed \\
\hline 26 & No interest in school & 33 & 20 & 41 & 11 & 2.7143 & Agreed \\
\hline 27 & Pregnancy by a child & 24 & 58 & 14 & 9 & 2.9238 & Agreed \\
\hline 28 & Love of money or get rich quick syndrome & 18 & 51 & 33 & 3 & 2.8000 & Agreed \\
\hline 29 & Negative peer influence & 55 & 34 & 12 & 4 & 3.333 & Agreed \\
\hline 30 & Early marriage practice & 27 & 70 & 5 & 3 & 3.1524 & Agreed \\
\hline 31 & Frequent communal conflict & 46 & 39 & 18 & 2 & 3.229 & Agreed \\
\hline 32 & Societal cultural practice & 26 & 44 & 22 & 13 & 2.7905 & Agreed \\
\hline 33 & Belief that only male child should be educated & 19 & 57 & 24 & 5 & 2.8571 & Agreed \\
\hline 34 & Value system in the society, i.e. belief that education is not profitable. & 23 & 63 & 15 & 4 & 3.000 & Agreed \\
\hline
\end{tabular}

To answer this question, an expected mean was calculated $(4+3+2+1) / 4=10 / 4=2.5)$. Any item with mean below 2.5 , being the expected mean, is rejected, while items with mean with 2.5 and above are accepted. As revealed in the table, poverty of parents/guardians, culture, tradition or religious belief of the family, parents lack of interest and awareness in education, care of siblings/ or relatives, unfavorable government policies, insufficient allocation to secondary school, high cost/fee, selection method in Common Entrance Exams, fear of high level unemployment in the country i.e. that job will not be available at the end of tanning, among others are influencing access to secondary education.

\section{Test of Hypotheses \\ Hypothesis 1}

Home factors have no significant effect on students' access to secondary education. 
Table-4: Chi-square analysis showing the effect of home factors on access to secondary education

\begin{tabular}{|c|c|c|c|c|c|c|c|c|}
\hline \multirow[t]{2}{*}{$\mathrm{S} / \mathrm{N}$} & \multirow[t]{2}{*}{ ITEMS } & \multicolumn{2}{|l|}{ AGREE } & \multicolumn{2}{|c|}{ DISAGREE } & \multirow[t]{2}{*}{ df } & \multirow[t]{2}{*}{$x^{2}$ cal. } & \multirow[t]{2}{*}{$x^{2} t a b$} \\
\hline & & $\mathrm{N}$ & $\%$ & $\mathrm{~N}$ & $\%$ & & & \\
\hline 1 & Poverty of parent/Guardian of students & 89 & 84.8 & 16 & 25.2 & \multirow{5}{*}{11} & \multirow{5}{*}{64.71} & \multirow{5}{*}{19.68} \\
\hline 2 & Culture, tradition or religious belief of the family & 73 & 69.6 & 32 & 30.5 & & & \\
\hline 3 & Parent lack of interest and awareness in education & 70 & 66.6 & 35 & 33.3 & & & \\
\hline 4 & Care of siblings/ or relatives & 68 & 64 & 37 & 25.2 & & & \\
\hline 5 & Lack of education of parents/ guardians & 40 & 38.1 & 65 & 61.9 & & & \\
\hline
\end{tabular}

The result of the chi square $\left(x^{2}\right)$ analysis, as indicated in Table 4, shows that $x^{2}$ calculated is greater than $x^{2}$ tabulated at 0.05 level of significant $(64.71>19.68)$. Therefore, the null hypothesis is rejected. This implies that Home factors have significant effect on students' access to secondary education.

\section{Hypothesis 2}

School factors have no significant effect on access to secondary education.

Table-5: Chi-square test on effect of school factors on access to secondary education

\begin{tabular}{|c|c|c|c|c|c|c|c|c|}
\hline \multirow[t]{2}{*}{$\mathrm{S} / \mathrm{N}$} & \multirow[t]{2}{*}{ ITEMS } & \multicolumn{2}{|c|}{ AGREE } & \multicolumn{2}{|c|}{ DISAGREE } & \multirow[t]{2}{*}{ df } & \multirow[t]{2}{*}{$x^{2}$ cal. } & \multirow[t]{2}{*}{$x^{2} t a b$} \\
\hline & & $\mathrm{N}$ & $\%$ & $\mathrm{~N}$ & $\%$ & & & \\
\hline 1 & Inadequate teacher to teach students & 91 & 86.6 & 14 & 13.4 & \multirow{14}{*}{18} & \multirow{14}{*}{45.22} & \multirow{14}{*}{28.87} \\
\hline 2 & Inadequate infrastructural facilities & 93 & 88.6 & 11 & 11.5 & & & \\
\hline 3 & Gender discrimination & 62 & 59.1 & 53 & 40.9 & & & \\
\hline 4 & Insecurity in Schools & 85 & 81 & 20 & 19.1 & & & \\
\hline 5 & Students avoidance of harassment or corporal punishment & 81 & 77.2 & 24 & 22.9 & & & \\
\hline 6 & Inability to understand medium of instruction & 73 & 9.5 & 32 & 30.5 & & & \\
\hline 7 & Poor quality of teaching by teacher & 90 & 85.7 & 15 & 14.3 & & & \\
\hline 8 & Irrelevant curriculum in school & 67 & 162.8 & 38 & 36 & & & \\
\hline 9 & Long distance of home to school & 76 & 74.3 & 29 & 27 & & & \\
\hline 10 & Limited admission spaces & 73 & 69.5 & 32 & 30.5 & & & \\
\hline 11 & Inappropriate teaching method & 53 & 50.5 & 52 & 49 & & & \\
\hline 12 & $\begin{array}{l}\text { Perception that a child is too young or immature to attend } \\
\text { school }\end{array}$ & 69 & 65.7 & 36 & 34 & & & \\
\hline 13 & Lack of water and sanitation in school & 89 & 84.8 & 16 & 15.2 & & & \\
\hline 14 & Negative attitude of teachers & 67 & 62.8 & 38 & 36 & & & \\
\hline
\end{tabular}

The result of Chi-square $\left(x^{2}\right)$ analysis, as indicated in Table 5 shows that $x^{2}$ calculated is greater than $x^{2}$ tabulated at 0.05 level of significant $(45.22>28.87)$. Therefore, the null hypothesis is rejected. This implies that School factors have significant effect on students' access to secondary education.

\section{Hypothesis 3}

Government factors have no significant effect on access to secondary education.

Table-6: Chi-square analysis on effect of government factors on access to secondary education

\begin{tabular}{|c|c|c|c|c|c|c|c|c|}
\hline \multirow[t]{2}{*}{$\mathrm{S} / \mathrm{N}$} & \multirow[t]{2}{*}{ ITEMS } & \multicolumn{2}{|c|}{ AGREE } & \multicolumn{2}{|c|}{ DISAGREE } & \multirow[t]{2}{*}{ df } & \multirow[t]{2}{*}{$x^{2}$ cal. } & \multirow[t]{2}{*}{$x^{2} t a b$} \\
\hline & & $\mathrm{N}$ & $\%$ & $\mathrm{~N}$ & $\%$ & & & \\
\hline 1 & Unfavorable government policies & 99 & 94.3 & 6 & 5.8 & \multirow[b]{5}{*}{8} & \multirow[b]{5}{*}{66.86} & \multirow[b]{5}{*}{15.51} \\
\hline 2 & Insufficient allocation to secondary school & 79 & 75.2 & 26 & 24.8 & & & \\
\hline 3 & High cost/fee & 97 & 92.4 & 8 & 7.6 & & & \\
\hline 4 & Selection method in common entrance exams & 87 & 92.4 & 18 & 17.2 & & & \\
\hline 5 & $\begin{array}{l}\text { Fear of high- level unemployment in the country i.e. that job will not } \\
\text { be available at the end of tanning }\end{array}$ & 84 & 80 & 11 & 20 & & & \\
\hline
\end{tabular}

As indicated in Table 6, the result of chi-square $\left(x^{2}\right)$ analysis shows that $x^{2}$ calculated is greater than $x^{2}$ tabulated at 0.05 level of significant $(66.86>15.51)$. Therefore, the null hypothesis is rejected. This implies that government factors has significant effect on students' access to secondary education

\section{Hypothesis 4}

There is no significant difference between the perception of male and female principals on the factors influencing challenges of access to secondary education. 
Table-7: t-test showing difference between the perception of male and female principal on the factors influencing access to secondary education

\begin{tabular}{|l|l|l|l|l|l|l|}
\hline Group & N & Mean & SD & d.f & t-cal & t-tab \\
\hline Male Principal & 69 & 101.84 & 8.28 & 103 & 0.119 & 1.980 \\
\cline { 1 - 4 } Female Principal & 36 & 101.64 & 8.24 & & & \\
\hline
\end{tabular}

As indicated in Table 7, t-cal $(0.119)$ is less than t-tab (1.980) at 0.05 level of significance. The null hypothesis is therefore accepted. This implies that there is no significant difference between the perception of male and female principal on the challenges of access to secondary education.

\section{Discussions}

Findings from the analysis of the data established that there are many factors influencing access to secondary education in Nigeria; such as poverty of parents/guardian, culture, traditional or religious belief, unfavourable government policies, inadequate teachers, child ill health, and early marriage etc. This finding agrees with that of Adegbenga et al. [26] who noted that factors influencing access to secondary education varies from one part to another and from region to region within the country; and includes poverty of parents/guardian of students, culture, traditional or religious belief, unfavourable government policies, inadequate teachers to teach students, child ill health early marriage etc.

Finding from hypothesis 1 revealed that home factors have significant effect on students' access to secondary education. This finding agrees with those of Wikan [13], Wachiye and Nasongo [16], Kuranja [8], among others, as contained in the reviewed literature. Hypothesis 2 reveals that school factors have significant effect on access to secondary school. This argument is in consonance with those of Wikan [13], Calchough, Sammer and Rose [27] among others, as indicated in the reviewed literature.

From Hypothesis 3, it was found that government factors significantly affected students' access to secondary education. This finding agrees with those of Wikan [13], Uduak [19], among others, as indicated in literature reviewed. In addition, the study found no significant difference in the perception of male and female principals on factors influencing access to secondary education. This could have due to the objectivity shown by the respondents while completing the questionnaires.

\section{ConcLusion and ReCOMmEndations}

It can be concluded from this study that there is still less than one hundred percent access to secondary education in Nigeria, in spite of the role it plays in national development and the strategic position it occupies in the educational system. Improving access to secondary education has however over the years been an extremely complicated and vexing problem for schools and education policy makers. Also, many factors interact to influence access to secondary education. Although there have been huge investments on secondary education by Federal and State Governments in Nigeria, this challenge seems not to have been appropriately addressed.

\section{Based on the findings, it is recommended that}

- Government should address the factors influencing access to secondary education through relevant policies and programmes;

- Government should engage communities, homes and families in sensitization programmes towards discouraging them from culture, traditions and religious belief that has negative influence on access to secondary education;

- Government should provide necessary infrastructural facilities for secondary schools, to enhance comfortability of students and teachers:

- There should be attractive welfare package, remunerations for teachers and prompt payment of teachers' salary;

- Emphasis should be laid on orientation of the citizens, change our value system and make the society well informed about the dangers of illiteracy; and

- Government should promote global best practices in management of our secondary education system.

\section{REFERENCES}

1. Matthew, I. A. (2013). Provision of secondary education in Nigeria: Challenges and way forward. Journal of African studies and Development, 5(1), 1-9.

2. Ike, P. (2017). Problems and Prospects of Secondary Education in Nigeria International Journal of Education and Evaluation, 13(1), 44-52

3. Adesina, S. (1982). Planning and educational development in Nigeria. Board Publications.

4. Nwagwu, N.A. (2015). One hundred Years of Education in Nigeria: Developmental Challenges, Achievements and Future Prospects. African Journal of Studies in Education, 10(1), 41-68

5. Federal Ministry of Education. (2017). Nigeria Education Indicators: 2012-2016. Abuja, Nigeria: Federal Government Press.

6. Federal Republic of Nigeria. (2004). National Policy on Education (Revised). Abuja, Nigeria: Federal Government Press. 
7. Okeke, E.A.C. (2009). Access in Nigerian education. In B.G. Nworgu \& E.I. Eke (Eds.) Access, quality and cost in Nigerian education). Proceedings of the 23rd Annual Congress of the Nigerian Academy of Education, 20-34.

8. Kuranja, D. M. (2014). Home based factors influencing access to Early Childhood Education in Limuru District, Kenya. M.ED Project in Economics of Education, University of Nairobi.

9. Aluede, O., Idogho, P.O. and Imonikhe, J.S. (2012). Increasing access to university education in

10. Nigeria: Present challenges and suggestions for the future. The African Symposium, 12(1): An Online Journal of the African Educational Research Network Retrieval on 17th December, 2015 from www. edu/aern/TAS12.1/TAS12.1Aluede.pdf

11. Adiukwu, M.U. $\left(2009,24^{\text {th }}-28^{\text {th }}\right.$ May). Nigeria country's report in post-basic S\&T education. Paper presented at the International Council of Association for Science Education (ICASE) held at Abuja, Nigeria.

12. United Nations Development Programme. (2016). Human Development Report. New York, USA

13. Wikan, U. (2008). In honor of Fadime: Murder and shame. University of Chicago Press.

14. Kepng'etich., Boit J.M., and Bonnett E.C. (2013).Factors Influencing Household Decisions on Access to Primary School Education in Kenya: Case Study of Uasin Gishu West District. International Journal of Academic Research in Business and Social Sciences, 3(7), 163-173

15. Ajayi, T., Shofoyeke, A. (2003). School discipline, teachers attitude and ethics of the teaching profession Paper presented at the workshop on skills improvement programme for performance of teachers in Ondo State, Nigeria.

16. Wachiye, J. H., \& Nasongo, W. J. (2010). Access to Secondary School Education through the Constituency Bursary Fund in Kanduyi Constituency, Kenya. Educational Research and Reviews, 5(5), 224-236.

17. World Bank. (2007). The World Bank Annual Report 2007. The World Bank.

18. Igbuzor, O. (2006). The State of Education in Nigeria; a keynote address delivered at a roundtable organized by Civil Society Action Coalition on Education for All (CSACEFA) on 3rd July, 2006. Garki, Abuja.

19. Uduak, E. (2018). Issues on Access and Equalization of University Educational Opportunities in Nigeria. Scholars Journal of Arts, Humanities and Social Sciences.

20. Limaye, S. (2016). Factors Influencing the Accessibility to Education for children with Disabilities. India Global Education Review, 3(3). $43-56$

21. Mollel, N. S., \& Chong, R. (2017). Socio-cultural Constraints of Girls' Access to Education in Mtwara District, Tanzania.

22. Kamanja, P. W., Kagunye, W. C., Kaguma, V. W., Kabuku, M. M., Mung'ara, E., Ibrahim, A., ... \& Abdulmajid, L. K. (2012). Factors Influencing the Boy-Child Secondary Education in the Rice-Growing region of Kirinyaga South District, Kirinyaga County, Kenya. Unpublished project Department of Educational Management, Policy and Curriculum studies, Kenyatta University. Retrieved from http://www. irlibrary. ku. ac. ke on, 30.

23. Gatta, M., Ngware, M. W., Onsomu, E. N., Muthaka, D. I., \& Manda, D. K. (2006). Improving access to secondary education in Kenya: what can be done?. Equal Opportunities International.

24. Okumu, Walter, Mena. (2014). Socio-economic factors influencing students' access to secondary school education in Rongo District of Kenya. .M.'ED Project, University of Nairobi, Kenya.

25. Oluwatayo, I. B., \& Ojo, A. O. (2017). Determinants of Access to Education and ICT in Nigeria. literacy, 9(4), $153-163$.

26. Adeyemi, J. K., \& Ige, A. A. (2002). Examination malpractices in Nigerian educational system: Causes, effects and the way out. Nigerian Journal of Clinical and Counselling Psychology, 8(1), 57-76.

27. Ahmed, T. M. (2003). Education and national development in Nigeria. Journal of studies in Education, 10(1), 35-46.

\section{QUESTIONNAIRE}

Dear Sir/Ma,

I seek your view on the factors influencing access to secondary education in Nigeria. You are pleased required to answer the questions in Sections A and B. Where applicable, tick one of the boxes provided. The questions are meant for educational research purpose only. Whatever information supplied by you will be used for the intended purpose and treated confidentially.

\section{SECTION A; BACKGROUND INFORMATION}

Name of School:

Local government area: Ondo East Local Government [ ] ] Ondo West Local Government [ ] ]Akure North Local Government [ ] Akure South Local Government [ ] lfedore Local Government [ ]ldanre Local Government [ ]

Type of School: Public [ ] Private [ ] Single Sex Boys [ ] Single Sex Girls. [ ] Coeducational (Mixed) [ ] Age Range of School: Below 10 years [ ] Between 10-20 years [ ] Between 20-30 years [ ] Above 30 years [ ]

Sex: Male [ ] Female [ ]

Marital Status. Married [ ] widow/ widower [ ]

Highest Qualification: B.SC/BA/HND/B.TECH. [

B.ED/B.SC.ED/B.A/ED [ ] B.SC/HND/B.TECH+PGDE. [ ] Others

Level of Experience: below 10 years [ ] Between 10-20 years [ ] Between 20-30 years [ ] Above 30 years [ ] 


\section{SECTION B}

Each statement in this section is followed by four options: Strongly Agree (SA), Agree (A), Disagree (D), and Strongly Disagree (SD). You are required to read each statement and tick the best option in response to the statement.

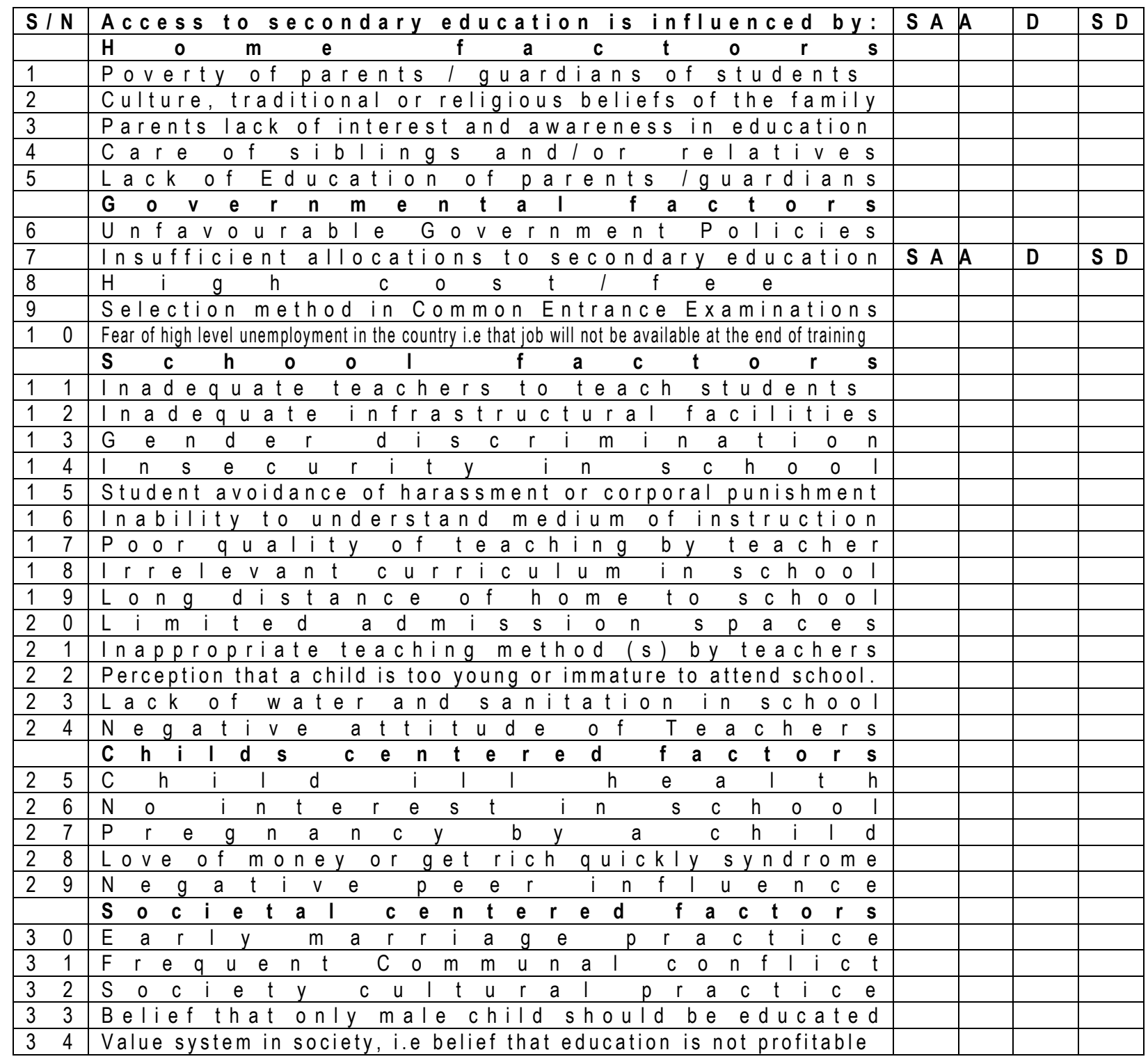
Please suggest other factors not listed: 